\title{
Cross-cultural Communication in Russian Advertising
}

\section{Elena Nikolaeva}

\author{
PhD in Culturology, Associate Professor, Institute of Social Engineering
} Moscow State University of Design and Technology (Moscow, Russia)

\section{Doi:10.5901/mjss.2015.v6n6s5p250}

\begin{abstract}
The processes of globalization/glocalization in contemporary world give rise to s cross-cultural communication across the cultures (Gudykunst, 2003) where a crucial role is played by advertising. The current investigation is dedicated to cross-cultural aspects of Russian advertising and deals with the adverts created for Russian and foreign companies working in Moscow in late 2000s to mid 2010s. The study aims to highlight not so much economical or political components of cross-cultural advertising communications as their cultural constituents. The analysis of textual and visual content of the adverts based on the semiological approach (Barthes, 2013) showed that cross-cultural communication in advertising in Russia mostly involves "global symbols" (Urri, 2002), well-known touristic referents of concrete cultures. Symbols from the sign systems of different cultures are not only translated by advertising by means of semantic codes alien to them, but the signs and their referents are re-encoded in a substantial way. The postmodern cross-cultural game in advertising constructs the culture's external and internal self-representations on the basis of its external ethnic images which have developed in foreign cultures. Cross-cultural communication in Russian advertising creates a multi-layered blend of cultures and imparts new cultural meanings into authentic artifacts and images and the semiosphere of the intercommunicating cultures in general.
\end{abstract}

Keywords: cross-cultural communication, cross-cultural advertising, Russian advertising, symbolic codes, culture external image, culture self-representation, semantic simulacra.

\section{Introduction}

It will not be a great exaggeration to say that intercultural dialogue plays the leading role in all spheres of modern human relations - personal, social, economical, academic, etc. By analogy to interpersonal communication when a person communicates with a person, intercultural communications represent a dialogue of the subjects of culture who are bearers and representatives of intrinsic characteristics of their cultures. The essence of intercultural communication consists in mutual code conversion of cultural elements, significant for a successful communication process, to the sign systems of co-operating cultures.

For example, when communicating with the tribes of the Arctic coast Christian missionaries used to replace some words in the "Lord's Prayer" by their contextual analogues: «bread» - by «fish», «Our Lord» - by «Our boat owner». However, intercultural communication does not propose to import/export the signs and semiotic codes themselves. So, for instance, the knowledge of the rule existing in Russian culture about an obligatory odd quantity of flowers in a bouquet allows an American to carry out intercultural dialogue successfully, but it will not induce him to apply this rule in daily communications in his own, American culture.

Today cultural foundations are taken into account in different fields of human interaction - in business negotiations, corporate management, educational courses, marketing programs, advertising campaigns, etc. Accordingly, theoretical and practical problems of intercultural and cross-cultural communications, including applied items, became a subject of thorough scientific research. As the main tool of intercultural communications is the natural language the issues of adequate interpretation and perception of verbal texts derived from foreign cultures constitute the central point of consideration.

In Russia linguistic aspects of intercultural communications as well as ideas of national lingua-conceptual spheres and language world-images are being elaborated by O. Leontovich (2005), S.G. Ter-Minasova (2004), A.V. Pavlovskaya (2008) and others. The transformations of the lingua-personality due to intercultural communications make particular interest. These investigations are closely connected with cultural psychology and comparative studies on cultural anthropology and the concept of the "national character". Another side of intercultural communications is concerned with non-verbal messages delivered by means of visual images such as illustrations, pieces of art, gestures, mimics, clothes and so on. 
What is more, processes of globalization/glocalization in contemporary world give rise to a very complicated type of an intercultural - both direct and indirect - dialogue which is defined as cross-cultural communication across the cultures (Gudykunst, 2003). Being a part of mass-culture and every day life, advertising serves as a relevant subject for empirical research and scientific reflection turns to the issues of cross-cultural advertising (Samiee \& Jeong, 1994).

Along with that, academic studies dedicated to cross-cultural communication in Russian advertising are not very voluminous. There is a number of works considering cross-cultural advertising in Russia from the sociological perspective (Ustinova, 2006; Wells, 2003) or in the frames of cultural semiotics (Nikolaeva, 2010) but most investigations usually just reveal adapted western and oriental elements in Russian adverts with no cultural and semiological analysis.

\section{Research Method and Objectives}

The current research is based on semiological analysis of cross-cultural aspects in textual and visual content of the adverts created for Russian and foreign companies working in Moscow. Chronologically the study covers late 2000s to mid 2010s. The main proposition is that cross-cultural communication in advertising is not just a matter of an adoption and adaptation of some foreign elements by the other culture. Though there is an obvious semantic reference to crossroads, crossbreeding, hybridization here the most important feature of cross-cultural communications is the fact that it always contains reflection on the previous code system and the socio-cultural and communicative-semiotic background (prehistory) of both accepted and outgoing messages. In other words, in the process of cross-cultural communication there is a reproduction of certain constructs on the basis of the previous communicative experience. These constructs are attributed with the meaning of the original, the authentic in the other culture, and then they are embedded into the symbollarium of the receptor-country.

Thus in Russia of the last decades there has widely spread the practice of celebrating Russian New Year with the "rituality" which is ostensibly inherent to traditional Japanese New Year holidays: the clothes of the certain color correlating to the animal from the Japanese calendar cycle, corresponding dishes on the New Year's table, etc. It is absolutely ignored that the dates of the beginning of a new year in the Russian and the Japanese cultures are apart from each other more than for a month, and there is none of those New Year "traditions" in Japan. It was advertising to spread "the Japanese tradition" so widely in the Russian culture of symbolic consumption. In a similar way due to cross-cultural advertising communications pseudo-authentic foreign elements are able to be easily implanted into the semiosphere (the term by M.Lotman) of any culture.

The other side of cross-cultural communication is constructing by the culture of its own external and internal selfrepresentations on the basis of its external ethnic images which have developed in foreign cultures. Here is a vivid example, the Russian matryoshka (nested doll), which serves as an "icon of a nation" (in the terminology of the British sociologist John Urri (Urri, 2005, p. 158) for the other cultures.

The objectives of the current research are to consider some aspects of the cross-cultural communication in Russia carried out with the means of the advertising discourse. The investigation aims to highlight not so much economical or political components of cross-cultural advertising communications as their cultural constituents. Nowadays mass media are one of the main mechanisms forming conceptualization about the world, essence of things and specificity of various cultures. In the paradigm of general consumption it is advertising that creates a collective world-image and everyday knowledge of the own and foreign cultures. Indeed, in illustrated magazines advertising blocks are read with the same feeling of getting information as pages of news (Barthes, 2003, p. 451). Obviously, advertising discourse becomes a fully legitimate element of postmodern culture, creating not only cultural "texts" in Derrida's understanding, but also input points to the hypertext of contemporary world-wide culture.

Therefore, advertising represents intercultural communication of the second order (while direct communications of individuals or collectives (companies, sport fans, tourists, etc.) from different cultures refer to the first order intercultural communications). However, unlike painting and literature which also appertain to the mediated types of intercultural communications, the advertisement of an object from another culture is never just descriptive, stating, informing or analytical, but always - constructing and mythologizing, creating a virtual remake of this object in own culture, whether it is «the true English tea» or «the Egyptian pyramid». Its parameters are defined by the optics of vision inherent in importing culture and concrete marketing tasks.

Rendering newer and newer "reformatted" copies, advertising simultaneously relegates an initial artifact to the level of a cultural prototype and elevates to a cultural myth. Numerous virtual copies made on the advertising conveyor transform the original into fiction, in one of the "versions" of itself. One of qualities, including those attributed by the advertising, which becomes a dominant of a foreign image (an antiquity, eccentricity, refinement, technological perfection, etc.), appears as the basic significant of the culture. This "hyper-symbol" of the culture - an element of an architectural or 
natural landscape, a historical character or an everyday thing, a dance or a meal, recognized all over the world, absorbs all others meaning. In a case of historically and ethnically "multilayered" culture (for example, Russian or American) there is a certain set of "hyper-symbols". Gradually it even starts to appoint discourse rules of external and internal selfrepresentations of this culture (from tourist booklets to ethnic cuisine restaurants). The bear, the matryoshka (a nested doll), the troika (a three-horse sleigh), the samovar, and the like become a stereotyped advertising mark of the "Russian tradition" and the "Russianness" in general (Fig. 1).
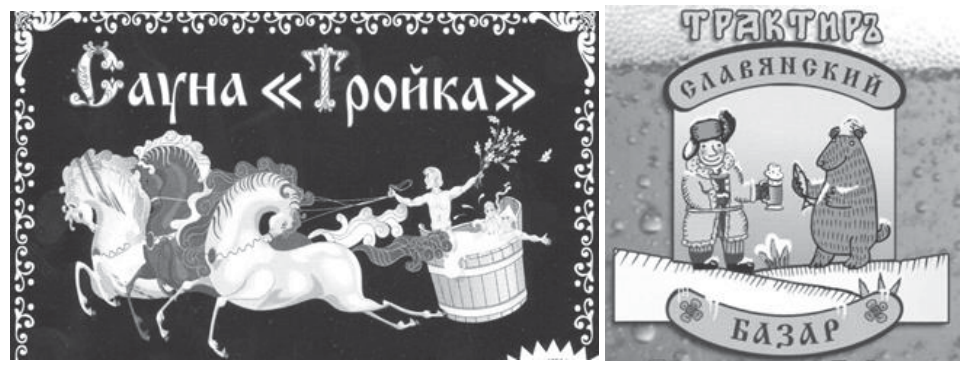

Figure 1. Some of the "hyper-symbols" of Russian culture: the ads of the Troyka bathhouse and the Slavyansky Bazar restaurant

Source: the author's photo of outdoor adverts

\section{Results}

Cultural difference and national originality are quite often accented in contemporary advertising of different goods and services. A bright example of such tendency is the series of Russian ad cards promoting the Italian liquor "DISARONNO Originale" which offer a bright nationally-tinged symbolical context together with the drink. That is, in the ad the notion "original(e)", meaning "true" and "first-hand", is transformed into "unusual" and "eccentric", the singularity being defined as American, French, Icelandic, etc. For instance, the American way of "originality" is shown through a youths' Internetchat where Redhead invites Shameles to a dancing party. There are a few references to American culture in their dialogue: they mention Independence Day and Coca-Cola. The main "original" is intended to be DiSarrono made "Americanly": "1 part of DiSarrono Original, 3 parts of Coca-Cola. Add some ice and mix up. Put the tongue-tip under the sweet bubbles and then drink merrily".

Similarly the French way of drinking DiSaronno is called "French Connections" and suggests 1 part of DiSarono and 1 part of cognac without cooling, without ice, and singing a young Breton girl's song "I seduce all the men..." (there is the text of the song in Russian on the reverse side of the card). The "Frenchness" is depicted by the Eiffel Tower, an old street of Paris, a pretty young girl and a passionate love song (Fig. 2). Thus an Italian product is virtually reformatted into a "French" thing with the use of symbolic tools from the Russian semiosphere.

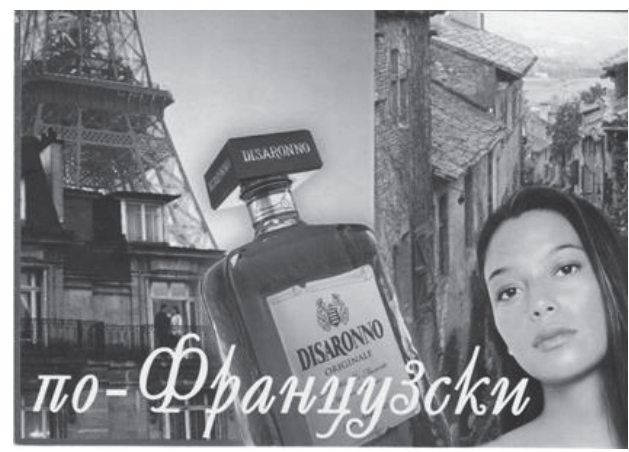

Figure 2. DiSarrono Originale Advertising CC-communication in Russia: The French Style.

Source: A card from the author's archive 
It is indicative that concept the «national Russian» modern domestic advertising fills mainly with the "traditional" Russian cuisine and national crafts, keeping the western optics of vision on Russian culture and even hypertrophying hackneyed images to symbolical representatives of the whole Russian culture. So the advertising block on the plasma screen, inviting to the «1-2-3» cafe in Pushkin Square in Moscow, opens with the caption "Sdelano v Rossii" (made in Russia) on a red background, with a white pattern simulating an embroidery in the corner. Then, replacing each other, three pictures appear on the screen: 1) the caption "1-oe" (the 1 ${ }^{\text {st }}$ ) and the images of a plate with borsch and a nested doll in a red kerchief nearby; 2) "2-oe" (the $2^{\text {nd }}$ ), a plate with pelmeni and a balalaika ; 3 ) "3-e" (the $3^{\text {rd }}$ ), a faceted tumbler filled with vodka, a pickle, a samovar (Fig. 3). As they say: no comments ...

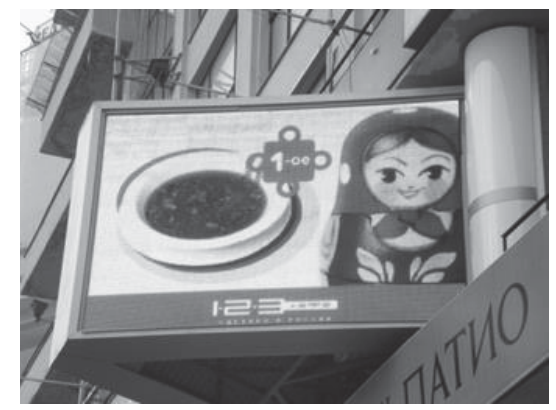

Figure 3. Advertising of 1-2-3 Café in Pushkin Square, Moscow, Russia.

Source: the author's photo

Such advertising demonstrations of hypertrophied ethnicity named as "staged authenticity" (MacCannell, 1973), represent a materialized articulation of modern mythologies. The fake image duplicated by advertising is made of the subjectssimulacra which serve as some kind of commodity labels of a national culture. Thus, "streltsy" (old Russian gunmen) outside "Russian" restaurants, "tsars" and "tsarinas" near Russian History museums, the caps with ear-flaps sold as Russian souvenirs, etc. become advertising markers for "Russian" culture. Thanks to advertising communications theatrical historical "reconstructions" arise inside modern city cultures or, speaking with M. Bakhtin's words, the "carmivalization" of everyday life takes place. Moreover, the option of "cultural diversity" which has become fashionable nowadays simultaneously legislates a deep conservative orientation at the own culture and exclusively touristic relation to other cultures (Luhmann, 2005, p. 134).

Another interesting example is presented by the ads of the "Russkiy stil"' (Russian Style) cigarettes. In the 1990s their ads were based on the images from Russian bylinas: a courageous warrior, a beautiful girl and a narrator playing the gusli. But since the middle of the 2000s the tobacco Russian style has been defined by a slogan "The style defines the quality". The quality of "the Russian style" is described with a foreign term "premium". At the same time the ad reads: "We have thing to be proud of - Russian culture, Russian soul, Russian generosity, Russian love... We have our own inimitable style, so do our cigarettes...". And the illustration displays quite "western" character types: a slim woman in a tightly fitted red cocktail dress and a man dressed in a white suit. From the iconographic point of view the gestures and the posture of the couple refer to the stylistics of glossy magazines and fashionable catalogues: the man embraces the woman, having put his hand on an abrupt bend of her hip; the woman standing with her back to the man, has languorously put her hand behind her companion's neck. It is remarkable, that the faces of the couple "have not gone into" the ad-board, they are "cut off" by its upper edge - possibly because the western type of a corporality still cannot entirely fit into the traditional-Russian idea about the Russian style.

On the other hand, one of the outdoor adverts of Danon's "Actimel" (Ehrmann) involves the traditional Khokhloma pattern (a Russian folk craft of painting on wood), but the customary strawberries and currant berries have been replaced by a peach and sea-buckthorns. The German company "Ehrmann" offers the sour cream named "Smetana Smetanovna" (Fig. 4) to the Russian consumer (smetana means sour cream, Smetanovna is a construction used in the Russian second name formed after the first name of the person's father). A portly rural woman with Gzhel flowers (traditional Russian blue painting on white porcelain dishes) on the packing draws a habitual external image of Russia. It is remarkable to a high extent that there is a recurrent attempt to build a usual external image into modern internal self-perception of Russians appealing to the Russian tradition on the three levels: a folklore name-patronymic, a rural character, national craft). The situation with the "Yoghurt Yoghurtovich" is analogous. 


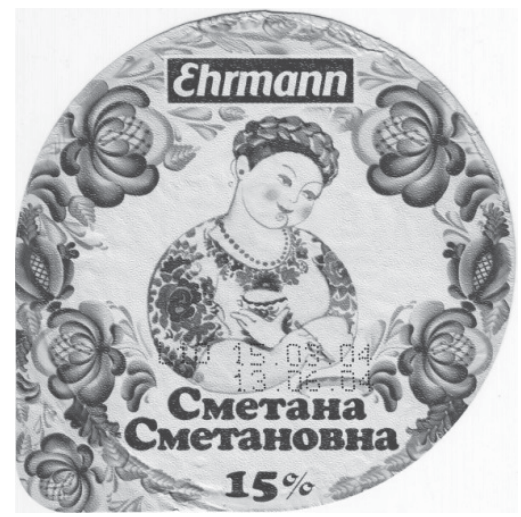

Figure 4. The packing design of the Smetana Smetanovna sour cream.

Source: the author's photo

\section{Discussion}

Cross-cultural advertising representations of the own culture and a foreign one can be met practically in all spheres of everyday culture: food, clothes, interiors, tourism and international business. Thus, in a business newspaper nested dolls of different sizes illustrate the growth of the shares value of a Russian company, in the ads of Moscow-Madrid flights they flaunt in sun glasses, and the social ad (with Francis Bacon's quotation «Love to the Motherland begins with the family») in the Moscow underground is accompanied by an image of the "family" of painted nested dolls. In Moscow there are restaurants "Matryoshka" and "Yadryona-Matryona". It is remarkable, that in symbolical self-identification of the Russian abroad the image of a nested doll is also met quite often (for example, the shop of the Russian community in the French city of Nice is called "Matryoshka"). It is easy to notice, that the nested doll as the cultural form contains semantic references to femininity, matriarchality, rural craft culture; accordingly, the occurrence of matryoshka as a sign means in advertising communications involuntarily accents these characteristics of the Russian culture. The signs of local tradition and foreign symbols generate a new semiotic space of culture described by R. Robertson's term "glocalization". Not only mixed advertising lexemes coexist there, such as "ARTEЛЬ", "Dяgilev", "Peresvet-Invest" (Peresvet is the legendary Russian saint warrior who defeated a Tartar fighter in 1380), "Obuv-city" (Footwear), etc., but also new semantic chimeras arise such as a souvenir rat (from the Japanese horoscope) playing the balalaika and executed in the techniques of Yaroslavl majolica, or a traditional wooden toy- bear from Sergiev Posed, knocking with its paws on the computer keyboard.

Considering the dynamics of advertising self-representations of Russia it can't be unnoticed that since postperestroika times lexical and graphical forms from foreign cultures have gained a high symbolic valence in Russian advertising self-identification. Those forms served to demonstrate Russia's integration into the western socio-economical paradigm. A special status of the western model for Russian culture was seen in the space of everyday life where recognizable nationally tinged lexemes belonging to Russian and English/American cultures were mixed together like in the names of music groups "Ivanushki-International" and "Balagan-Limited" (Show booth). Later on the usage of western socio-cultural patterns in Russian advertising discourse became more balanced. Nevertheless the English lexeme "city" (both in Roman type and in Cyrillic alphabet) is still wide-spread in Russian commercial names. It can mark European content of any market product - from the international business center ("MOSKVA-SITI" in Moscow, "SITI-TSENTR" in St. Petersburg, Novokuznetsk, Chelyabinsk, etc.) and purchase \& entertainment complexes ("KROKUS-SITI" in Moscow, "SITI-MOL" in Magadan, Kaliningrad, Saratov, etc.) to automobile sales centers ("Avto-siti"), stomatologic clinics ("DentalCity") and footwear stores ("Obuv'-siti"). The same tendency can be seen in the names of some Russian trademarks where Russian family names are transcribed in an foreign manner - to begin with the world famous vodka "Smirnoff" and so on: the florist's "Tsvetkoff" (tsvetok means flower), the beer restaurant "Kolbasoff" (kolbasa means sausage) and others.

In ads of subjects and phenomena of foreign origin images from those cultures mainly have index character (for example, Tour d'Eiffel as an index of Paris and France in whole or French cosmetics in particular, etc.). There are also complicated symbolical references when associative chains are not only multilayered, but also poorly motivated, like the 
advertising message about a Siberian cedar SPA complex (in a Russian magazine), illustrated by Leonardo da Vinci's well-known drawing just because the complex is executed "from a unique relic cedar, coeval to Michelangelo and Leonardo da Vinci". Thus, by the means of advertising rhetoric Russian Siberia becomes equivalent to the Italian classics.

It is necessary to remark, that within the frames of marketing strategy advertising sometimes produces absolutely new socio-cultural meanings connected with images of other cultures. As a result of an advertising "translating" (transfer) of socio-cultural realities into the language of another culture, postmodern games with national symbols, semantic "domestication" of images and their inclusion in the symbollarium of the own culture there occur different kinds of semantic simulacra (or simulacrum). Advertising representations of such kind are based both on historically developed, stereotypic external and internal images, and on the sign means (including linguistic and cultural) designed in the frameworks of "goods" promotion campaigns.

Thanks to advertising communications, foreign holidays (Halloween, Catholic Christmas, St. Valentine's Day, St. Patrick's, etc.) appear to be included into the semio-sphere of the Russian culture. In their turn the sign events and characters of Russian culture and history are used by some foreign companies seeking to gain Russian customers' loyalty (the butter "Doyarushka" (Milkmaid) from New Zealand) or the cigarettes "Peter I" manufactured by a Japanese tobacco corporation). The beer restaurant "Starina Miller" (Old Chap Miller) having a German fatty-burgher as a brandcharacter offers the action "The Lent" to its visitors on the corresponding days of the Russian Orthodox calendar. The obvious contradiction of keeping the fast and having a meal in a restaurant is left unnoticed.

\section{Conclusion}

The processes of globalization lead to interference and assimilation of foreign phenomena in local cultures and make cross-cultural collisions more and more usual. Symbols from the sign systems of different cultures are not only translated by advertising by means of semantic codes alien to them, but the signs and their referents are deformed like topographic maps in different projections. The significant and the designatum frequently are interchanged in their positions. The advertising constructs metaphorical and metonymic chains of associations, as though transposing the matrixes of national cultures, turn them outside - into global world culture. The best known cross-cultural symbol "thrown" into the global field of culture by advertising is Santa Claus in the Coca-Cola "packing" and its advertising synecdoche - the red cap with a white pompon. A "Japanese" lunch in a Moscow sushi-bar; the "Oktoberfest" at the Russian beer restaurants; the gastronomic and wardrobe "ceremonialism" of east horoscopes which has been built into Russian advertising narratives - they all are the things of the same nature.

To conclude it should be emphasized once again, that cross-cultural advertising communications more often become a form, in which tradition is shaped by modernity, and simultaneously they are the way of tradition transfer in synchronic layers of global culture. The pseudo-authenticity of "glocal" symbols is disguised by semiotic inertia of culture, and their simulation is legislated by the rules of the postmodernist game in which not only advertising is playing, but the entire modern culture. Along with that cross-cultural communications in Russian advertising create a multi-layered blend of cultures and impart new cultural meanings into authentic artifacts and images and the semiosphere of the intercommunicating cultures in general.

\section{References}

Barthes, R. (2013). Mythologies. (2nd ed.) New York: Hill and Wang.

Gudykunst, W.B. (2003). Cross-Cultural and Intercultural Communication. London: SAGE Publications.

Leontovich, O.A. (2005). Russkiye i amerikantsy. Paradoksy mezhkulturnogo obshcheniya [The Russians and the Americans. Paradoxes of intercultural communication]. Moscow: Gnosis.

Luhmann, N. (2005). Realnost massmedia [Massmedia reality]. Moskva: Pracsis.

MacCannell, D. (1973). Staged Authenticity: Arrangements of Social Space in Tourist Settings. American Sociological Review, 79, 589603.

Nikolaeva E.V. (2010). Kross-kulturnye kolizii: reklamnye representatsii Rossii [Cross-cultural collisions: Advertising representations of Russia]. Trudy Sankt-Peterburgskogo universiteta kultury i iskusstv, 190, 472-479.

Pavlovskaya, A.V. (ed.) (2008). Rossia i zapad: Dialog kultur [Russia and The West: The Dialogue of Cultures]. Proceedings of the 12th international conference]. Moskva: Izdatel'stvo Moskovskogo gosudarstvennogo universiteta.

Samiee, S., \& Jeong, I. (1994). Cross-Cultural Research in Advertising: An Assessment of Methodologies. Journal of the Academy of Marketing Science, 22(3), 205-217.

Ter-Minasova, S.G. (2004). Yazyk i mezhkulturnaya kommunikatsiya [The Language and Intercultural communication]. Moscow: 
Izdatelstvo MGU.

Urri, J. (2002). Tourist Gaze. (2nd ed.) London: SAGE Publications.

Ustinova, I.P. (2006). English and emerging advertising in Russia. World Englishes, 25(2), 267-277.

Wells Gricenko, L. (1994). Western Concepts, Russian Perspectives: Meanings of Advertising in the Former Soviet Union. Journal of Advertising, 23(1), 83-95. 